Bangladesh J. Bot. 42(1): 17-22, 2013 (June)

\title{
PHYTOCHEMICAL CHARACTERISTICS, ANTIMITOTIC, CYTOTOXIC AND ANTITUMOR ACTIVITIES OF BARK EXTRACT OF STREBLUS ASPER LOUR
}

\author{
ANM Alamgir*, Minhajur Rahman and Ataur Rahman \\ Department of Botany, University of Chittagong, Chittagong-4331, Bangladesh
}

Key words: Streblus asper Lour, Secondary metabolites, Bark extract, Anticarcenogenic properties

\begin{abstract}
Ethanol extract of the stem bark of Streblus asper Lour was considered for qualitative assessment for its secondary metabolites content like alkaloids, glycosides, sterols and others. Bark extract revealed anticarcenogenic i.e. antimitotic, cytotoxic and antitumor activities. Results of different anticarcenogenic activities of the bark extract were discussed in relation to its secondary metabolite contents.
\end{abstract}

\section{Introduction}

Traditional medicinal plants have been recognized for their therapeutic benefits for centuries (Leonti et al. 2003, Gurib-Fakim 2006). However, there are still many unanswered questions about the mechanism of action of herbal drugs (Spinella 2002). Streblus asper Lour or Tooth brush tree of the family Moraceae is indigenous to Bangladesh (Chowdhury 1996). It is a bushy evergreen tree with milky latex and is found to grow wild all over Bangladesh. S. asper stem bark is traditionally used in the treatment of leprosy, piles, diarrhea, dysentery, elephantiasis and other diseases (Ghani 2003, Yusuf et al. 2009, Kumar et al. 2011). However, the systematic study for anticarcenogenic i.e. antimitotic, cytotoxic and antitumor activities of the bark extract in relation to secondary metabolites content have not been performed. Therefore, the aim of the present research was to investigate these properties of the bark extract.

\section{Materials and Methods}

Collection of bark sample: Stem bark sample was collected from a medium sized Streblus asper plant, grown naturally in the premises of Botanical Garden, Department of Botany, Chittagong University, Bangladesh in August, 2010. The plant was identified and a voucher specimen (accession no. 2010-88) was kept in the department. The collected bark sample $(\approx 700$ g) was cleaned from undesirable materials, chopped, air dried in shade at room temperature and finally ground to a coarse powder.

Extraction: About $100 \mathrm{~g}$ powder was macerated with ethanol $(1: 5)$ in a sealed container for 5 days at room temperature with occasional shaking. Extract was filtered through Whatman No.1 filter paper and evaporated to dryness under vacuum below $50^{\circ} \mathrm{C}$ to get about $3 \mathrm{~g}$ blackish extract. The extract thus obtained was kept at $4^{\circ} \mathrm{C}$ for future use.

Assessment of secondary metabolites: Alkaloid detecting reagents were prepared following Cromwell (1955) and assessed according to Aplin and Cannon (1971). Flavonoids, tannins and sterols were determined following Wall et al. (1954), Farnsworth (1966) and Bhattachrjee and Das (1969), respectively. Glycosides, saponins and resins in the extract were assessed qualitatively according to Ghani (2005).

Bioassay: Antimitotic activity of the extract was determined according to Turker and Camper (2002) using wheat seeds at germination and early seedling growth stage, cytotoxicity by brine

*Author for correspondence: <alamgiranm@yahoo.com>. 
shrimp nauplii lethality assay according to Meyer et al. (1982) and antitumor effects by assessing inhibition of tumor growth on potato disc due to Agrobacterium tumefaciens (Galsky et al. 1980). Each set of experiment was replicated three times and their mean values were taken.

\section{Results and Discussion}

Medicinal plants have curative properties due to the presence of various secondary metabolites like alkaloids, terpenoids, phenolic compounds, glycosides, steroids etc. (Savithramma et al. 2012). In the present work, bark extract of S. asper was examined qualitatively for its alkaloid content using Dragendorff's (D), Wagner's (W), Mayer's (M), Hager's $(\mathrm{H})$ and Tannic acid $(\mathrm{T})$ reagents. The relative abundance of different secondary metabolites contents in the extract was expressed by ' + ' sign in different degrees signifying the abundance. Absence of any secondary metabolite was indicated by '-' sign. Results are given in Table 1.

Table 1. Qualitative assessment of different secondary metabolites in S. asper stem bark.

\begin{tabular}{lcccccccccc}
\hline \multicolumn{10}{c}{ Secondary metabolites } \\
\hline \multicolumn{10}{c}{ Alkaloid (Reagents used) } & \multicolumn{7}{c}{ Other secondary metabolites } \\
\hline $\mathrm{D}$ & W & M & H & T & Flavonoid & Glycoside & Resin & Saponin & Sterol & Tannin \\
\hline $2+$ & + & + & + & $2+$ & - & + & - & - & + & - \\
\hline
\end{tabular}

For alkaloid, all the five reagents gave positive result and the higher abundance was detected by Dragendorff's and Tannic acid reagents. Among other metabolites, positive responses were noted only for glycoside and sterol. The occurrence of different secondary metabolites in a medicinal plant suggests a wide range of its biological applications (Ramzi et al. 2008). Several alkaloids like vinblastine, vincristine, camptothecin, taxol etc. are successfully employed in cancer treatment (Syrovets and Laumonnier 2009). Glycoside derivatives also showed very promising activity in various in vitro and in vivo tests (Keller-Juslén et al. 1971) and two of them, ethylidene derivative, etoposide (Nakanomyo et al. 1986) and theylidene derivative, teniposide (van den Berg et al.1997), have been developed as anticancer drugs.

Inhibition of cell division is a measure of the antimitotic activity of chemical compounds. Growth inhibition test provides a way of detecting the antimitotic activity of chemical compounds under laboratory conditions.

In the present study, model of radish seed phytotoxicity assay described by Turker and Camper (2002) was used to evaluate growth stimulation or inhibition properties of the ethanol extracts of S. asper stem bark by taking wheat seed as test material. The seed germination counts taken on $5^{\text {th }}$ day following soaking were $56.00 \pm 01.20$ and $35.66 \pm 0.88$ at $1000 \mathrm{ppm}$ and 7500 ppm of extract, respectively (Fig. 1). The root lengths measured after the same time intervals were $15.83 \mathrm{~mm} \pm 0.34$ and $10.17 \mathrm{~mm} \pm 0.37$ at $1000 \mathrm{ppm}, 10,000 \mathrm{ppm}$ of extract, respectively (Fig. 2). All these indicate that inhibition of the protrusion of plumule and radicle through the seed hilum at germination and the elongation of the root at seedling growth stages were due to the suppression of mitotic cell division and higher doses were more effective in inhibiting such growth activities, possibly due to high content of secondary metabolites. Antimitotic chemical compounds such as vinblastine and podophyllotoxin have been shown to inhibit cell division (Jacobs et al. 1981, White and Jacobs 1981). Several antitumour drugs such as colchicine and its analogues, podophyllotoxin and vinca alkaloids also inhibit mitosis (Biswas et al. 1984, Islam et al. 2010). 


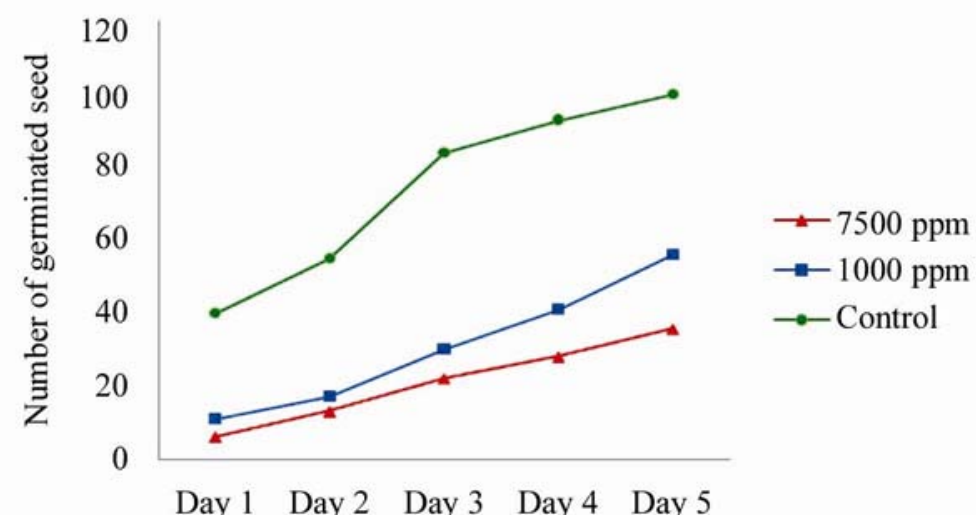

Fig. 1. Effects of Et-OH extract of S. asper stem bark on germination of wheat seeds.

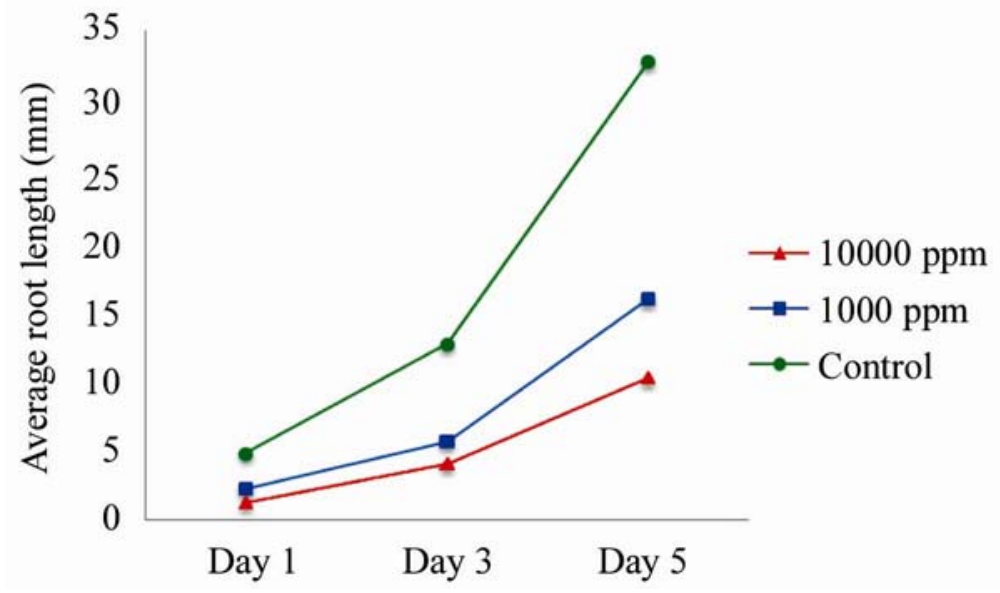

Fig. 2. Effects of Et-OH extract of S. asper stem bark on the rate of root growth in length of wheat seedlings.

Table 2. Cytotoxic effect on Artemia salina nauplii due to extract of $S$. asper stem bark.

\begin{tabular}{cccccccc}
\hline $\begin{array}{c}\text { Dose } \\
(\mu \mathrm{g} / \mathrm{ml})\end{array}$ & $\begin{array}{c}\text { Log } \\
\text { dose }\end{array}$ & $\begin{array}{c}\text { Total } \\
\text { nauplii }\end{array}$ & $\begin{array}{c}\text { Survived } \\
\text { nauplii }\end{array}$ & $\begin{array}{c}\text { Dead } \\
\text { nauplii }\end{array}$ & $\begin{array}{c}\text { Lethality } \\
(\%)\end{array}$ & $\begin{array}{c}\text { Actual } \\
(\%)\end{array}$ & Probit \\
\hline 10 & 1 & 10 & 10 & 0 & 0 & 0.025 & 3.04 \\
20 & 1.3 & 10 & 9 & 1 & 10 & 0.1 & 3.72 \\
25 & 1.4 & 10 & 8 & 2 & 20 & 0.2 & 4.16 \\
50 & 1.7 & 10 & 6 & 4 & 40 & 0.4 & 4.75 \\
75 & 1.9 & 10 & 2 & 8 & 80 & 0.8 & 5.84 \\
100 & 2 & 10 & 0 & 10 & 100 & 0.975 & 6.96 \\
\hline
\end{tabular}

The cytotoxic activity of the ethanol extract of $S$. asper stem bark extract was determined by the brine shrimp nauplii lethality bioassay using six concentrations of the extract ranging from 10 to $100 \mu \mathrm{g} / \mathrm{ml}$, each with 10 nauplii, which died progressively in greater number with the increase of 
the concentration of the extract and exposure time (up to 24 hours) at the rate of $0.025,0.1,0.2$, $0.4,0.8$ and $0.975 \%$ (Table 2).

In the present work, percent and probit were calculated using statistical software "Biostat 2009" and the bark extract showed $\mathrm{LC}_{50}$ value of $45.21 \mu \mathrm{g} / \mathrm{ml}$ (Table 3). Chi square value is insignificant at $5 \%$ i.e. the data between concentration and lethality is homogenous.

Table 3. Calculation of $\mathrm{LC}_{50}$ value, regression equation and confidence limit.

\begin{tabular}{cccccc}
\hline $\log \left(\mathrm{LC}_{50}\right)$ & $\begin{array}{c}\mathrm{LC}_{50} \\
(\mu \mathrm{g} / \mathrm{ml})\end{array}$ & $\begin{array}{c}95 \% \text { Confidence } \\
\text { limit }(\mu \mathrm{g} / \mathrm{ml})\end{array}$ & Regression equation & \multicolumn{2}{c}{ Chi square } \\
\cline { 4 - 6 } & 4.59 & $34.79-58.68$ & $\mathrm{Y}=-24.43+37.93 \times$ & Calculated & Tabulated \\
\hline
\end{tabular}

The cytotoxicity of plant material would likely indicate the presence of antitumor compounds in plant extract (Martin-Cordero et al. 1995). According to Rieser et al. (1996), crude extracts resulting an $\mathrm{LC}_{50}$ value of less than $250 \mu \mathrm{g} / \mathrm{ml}$ could be considered significantly active and potential for further investigation. The bark extract of $S$. asper exhibited $\mathrm{LC}_{50}$ value less than 250 $\mu \mathrm{g} / \mathrm{ml}$ indicating its potential as a source of anticancer agent. Coker et al. (2003) stated that the antitumor agent might inhibit the initiation and growth of tumors in both plant and animal systems. The inhibition of Agrobacterium tumefaciens induced tumors i.e. crown gall, a neoplastic plant disease, in potato disc tissue is an assay based on antimitotic activity and can detect a broad range of known and novel antitumor effects (McLaughlin and Rogers 1998). The crown gall tumor assay is one of several bench top bioassays recommended by the U.S. National Cancer Institute (NCI) for screening and making short list of plants with anticancer activity leading to the discovery of novel lead compounds (Lellau and Liebezeit 2003, Ahsan et al. 2007).

The ethanol extract of the present work exhibited the inhibitory activity in a dose dependent manner, the inhibitory effect being higher at high concentration of the extract (Fig. 3).
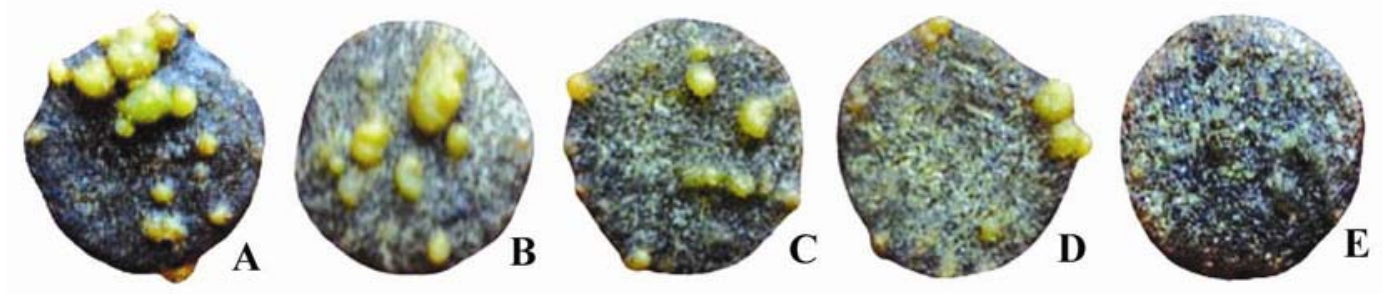

Fig. 3A-E. Effects of ethanolic extract of S. asper stem bark on crown gall tumor formation at different concentrations. A: negative control was without extract. B, C and D: treatment with 10, 100 and $1000 \mathrm{ppm}$ extract, respectively. E: positive control with $30 \mathrm{ppm}$ camptothecin.

The percent inhibition of tumor was compared with the standard tumor suppressor drug, camptothecin (positive control), which completely inhibited the growth of gall tumor on potato discs. Highly significant tumor inhibition e.g. 31.86 and $40.44 \%$ was observed at $100 \mathrm{ppm}$ and $1000 \mathrm{ppm}$ of the extract, respectively (Table 4). Plant extracts showing more than $20 \%$ tumor inhibition were reported to be significant (Ferrigini et al. 1982). Similar results were also reported by Islam et al. (2010) and Mazid et al. (2011) with other plant extracts. 
Table 4. Effect of $S$. asper stem bark extract on tumor formation on potato disces.

\begin{tabular}{lcc}
\hline Concentration $(\mathrm{ppm})$ & Mean number of Tumor \pm SE & \% of Inhibition \\
\hline Negative control (-extract) & $22.6 \pm 0.6782$ & - \\
10 & $18.5 \pm 0.2887$ & 18.14 \\
100 & $15.4 \pm 0.5099$ & 31.86 \\
1000 & $11.2 \pm 0.7348$ & 40.44 \\
Positive control (+camptothecin) & 0.00 & $100 \%$ \\
\hline
\end{tabular}

Coker et al. (2003) while studying the activity of antineoplastic drugs like camptothecin, paclitaxel, podophyllin, vinblastine and vincristine considered A. tumefaciens induced potato disc tumor assay as an effective indicator of antitumor activity.

\section{References}

Ahsan U, Ansari FL, Ihsan-ul-Haq, Nazir S and Mirza B 2007. Combinatorial synthesis, lead identification, and antitumor study of a chalcone- based positional-scanning library. Chemistry and Biodiversity 4: 203-214.

Aplin TEH and Cannon JR 1971. Distribution of alkaloids in some western Australian plants. Eco. Bot. 25(4): 366-380.

Bhattacharjee AK and Das AK 1969. Phytochemical screening of few Mysore plants. Econ. Bot. 23(3): 204-206.

Biswas BB, Sen K, Choudhury G and Bhattacharyya B 1984 Molecular biology of tubulin: Its interaction with drugs and genomic organization. J. Biosci. 6(4): 431-457.

Chowdhury MSU 1996. Bangladesh country report to the FAO international technical conference on plant genetic resource, Leipzig 1996. Appendix-3, 88-91 pp.

Coker PS, Radecke J, Guy C and Camper ND 2003. Potato tumor induction assay: a multiple mode of action drug assay. Phytomedicine: Intl. J. Phytotherapy \& Phytopharmacol. 10: 133-138.

Cromwell BT 1955. Modern method of plant analysis. Springer-Verlag, Berlin, pp. 373-374.

Farnsworth NR 1966.Biological and physiochemical screening of plants. J. Pharm. 55: 225-276.

Ferrigini NR, Putnam JE, Anderson B, Jacobsen LB, Nichols DE, Moore DS and McLaughlin JL 1982. Modification and evaluation of the potato disc assay and antitumor screening of Euphorbiaceae seeds. J. Nat. Prod. 45: 679-686.

Galsky AB, Wilsey JP and Powell RG 1980. Crown-gall tumor disc bioassay: a possible aid in the detection of compounds with antitumor activity. Plant Physiol. 65: 184-185.

Ghani A 2003. Medicinal plants of Bangladesh with chemical constituents and uses. Asiatic Society of Bangladesh, Dhaka. $196-197$ pp.

Ghani A 2005. Practical phytochemistry (including methods of phytochemical studies). Parash Publishers, Dhaka, Bangladesh. 11-19 pp.

Gurib-Fakim A 2006. Review: Medicinal plants: Traditions of yesterday and drugs of tomorrow. Mol. Aspects Med. 27: 1-93.

Islam MS, Rahman MM, Rahman MA, Qayum MA and Alam MF 2010. In vitro evaluation of Croton bonplandianum Baill. as potential antitumor properties using Agrobacterium tumefaciens. J. Agric. Tech. 6(1): 79-86.

Jacobs RS, White S and Wilson L 1981. Selective compounds derived from marine organisms: effects on cell division in fertilized sea urchin eggs. Fed. Proc. 39: 26-29.

Keller-Juslén C, Kuhn M, von Wartburg A and Stähelin H 1971. Synthesis and antimitotic activity of glycosidic lignan derivatives related to podophyllotoxin. Med. Chem.14: 963-968. 
Kumar RBS, Puratchikodi A, Prasanna A, Dolai N, Majumder P, Mazumder UK and Halde PK 2011. Pre clinical studies of Streblus asper Lour in terms of behavioural safety and toxicity. Orient Pharm Exp Med. 11: 243-249.

Lellau TF and Liebezeit G 2003. Cytotoxic and antitumor activities of ethanolic extracts of salt marsh plants from the lower saxonian wadden sea, Southern North Sea. Pharmaceutical Biology 41: 293-300.

Leonti M, Sticher O and Heinrich M 2003. Antiquity of medicinal plant usage in two Macro-Mayan ethnic groups (México). J. Ethnopharmacol. 88: 119-124.

Martin-Cordero G, Saenz MT, Ayuso MJ 1995. Cytotoxic activity of Retama spaerocarpa. Fitoterapia 16: 495-498.

Mazid MA Nahar L, Datta BK, Bashar SAMK and Sarker SD 2011. Potential antitumor activity of two polygonum species. Arch. Biol. Sci., Belgrade, 63(2): 465-468.

McLaughlin JL, Rogers LL 1998. The use of biological assays to evaluate botanicals. Drug Inform. J. 32: 513-524.

Meyer BN, Ferrigni NR, Putnam JE, Jacobson LB, Nichols DE and McLaughlin JL 1982. Brine shrimp: a convenient general bioassay for active plant constituents. Planta Medica 45: 31-34.

Nakanomyo H, Hiraoka M and Shiraya M 1986. Mutagenicity tests of etoposide and teniposide. J. Toxicol. Sci. 11: 301-310.

Ramzi AA, Mothana SA, Faisal AS and Lindquist A 2008. Antimicrobial, antioxidant and cytotoxic activities and phytochemical screening of some Yemeni Medicinal plants. Evidence-based Complementary and Alternative Medicine 7(3): 323-330.

Rieser MJ, Gu ZM, Fang XP, Zeng L, Wood KV, and McLaughlin JL 1996. Five novel monotetrahydrofuran ring acetogenins from the seeds of Annona muricata. J. Nat. Prod. 59: 100-108.

Savithramma N, Linga Rao M and Suhrulatha D 2012. Screening of medicinal plants for secondary metabolites. Middle-East J. Scientific Res. 8(3): 579-584.

Spinella M 2002. The importance of pharmacological synergy in psychoactive herbal medicines. Altern. Med. Rev. 7(2): 130-137.

Syrovets T and Laumonnier Y 2009. Project 1: Pentacyclic triterpenoids from the family of boswellic acids as antitumor agents: identification of effective molecular structures and molecular characterization of cytotoxic mechanisms. http:// www.uni-ulm.de/ klinik/nhk/dept/research/projekte Syrovets_neu.htm.

Turker AU and Camper ND 2002. Biological activity of common mullein, a medicinal plant. J. Ethnopharmacol. 82: 117-125.

van den Berg H, Wouter S, Behrendt H 1997. Treatment of Hodgkin's disease in children with alternating mechlorethamine, vincristine, procarbazine and prednisolone (MOPP) and adriamycin, bleomycin, vinblastine, and dacarbazine (ABVD) courses without radio- therapy. Med. Pediatr. Oncol. 29: 23-27.

Wall ME, Krider MM, Krewson CF, Eddy CR, Willaman JJ, Corell SS and Gentry HS 1954. Steroidal sapogenins. Survey of plants for steroidal sapogenins and other constituents. J. Pharm. 1-7.

White SJ and Jacobs RS 1981. Inhibition of cell division and of microtubule assembly by elatone, a halogenated sesquiterpene. 1981. Mol. Pharmacol. 20: 614-620.

Yusuf M, Chowdhury JU, Hoque MN and Begum J 2009. Medicinal plants of Bangladesh. BCSRI, Chittagong, Bangladesh. 762 pp.

(Manuscript received on 16 February, 2013; revised on 1 June, 2013) 